\title{
Different Garden Pea Varieties Health Status Analysis Procured from Various Locations of Odisha
}

\author{
S. P. Monalisa and Chakradhar Patra*
}

Dept. of Crop Physiology, Institute of Agricultural Sciences, Siskha 'O'Anusandhan (Deemed to be) University, Bhubaneswar, India

*Corresponding author

\begin{abstract}
A B S T R A C T
Keywords

Garden pea,

Germination,

Health status, Seed,

Fungi,

Pathogenicity

Article Info

Accepted:

22 June 2020

Available Online:

10 July 2020

Garden pea (Pisum sativum L.) is an important vegetable crop grown during winter season in Odisha. A number of seed borne pathogens affect seed which reduce seed quality and cause seed borne diseases in the field, adversely affecting yield and quality of produce. A study on thirty-six farmers' seed samples collected from eight districts to analyse the health status of Garden pea were found to possess seed germination 10-15\% which is below IMSCS (i.e. 75\%) and carried 40.1-46\% fungal count on seeds. Aspergillus flavus, A. niger, Fusarium sp. and Pencillium sp. were fungi frequently associated with seeds which caused $24.4-55.6 \%$ reduction in germination and caused rotting of seed and seedling shoot and root.

\section{Introduction}

Garden pea (Pisum sativum L.) is an important vegetable crop grown for its green pods and seeds. It is a frost-hardy, coolseason, nutritious leguminous vegetable which is widely cultivated throughout the world. In India, it is grown as a winter vegetable in the plains of north India and as a summer vegetable in the hills. It is a rich source of protein $(25 \%)$, amino acids, sugars (12\%), carbohydrate, vitamins $\mathrm{A}$ and $\mathrm{C}$, calcium and phosphorus, apart from having a small quantity of iron. Incidence of disease

outbreak is one of the major biotic factor responsible for low yield. Seed and seedling disease, root rot and stem rot disease caused by fungi like Fusarium spp, Rhizoctonia solani, Sclerotium rolfsi, Pythium species and powdery mildew are important disease of pea in India which affects the crop every year. However, lack of quality seed continues to be one of the greatest impediments bridging the vast yield gap. Therefore, to approach the potentially realizable yield of a cultivar, production and distribution of quality seed is essential. Present study was carried out to critically analyse quality status of garden pea
\end{abstract}


seeds used by farmers in Odisha with special references to know the seed health status.

\section{Materials and Methods}

\section{Collection of seed samples}

The seeds of different garden pea varieties grown during 2013-14 winter season were collected from farmers of different locations. The seeds were collected from local market in properly labelled polythene packets along with information on variety, month of harvest, storage container, storage place etc. and stored in seed cabinet for further use.

\section{Study of Seed health status of collected samples}

The seeds collected from the farmers were first visually observed to record the visible symptoms of diseases like patches of discoloration, mycellial mats and fungal fructifications attached to it, etc. To ascertain the association of fungal pathogens with the sample, the seeds were subjected to seed health test following standard moist blotter method (ISTA, 1985). For this test, clean and sterilized $11 \mathrm{~cm}$ diameter plastic petridishes were used. Three pieces of filter paper discs were dipped in sterile distilled water and fitted to the base of the bottom Petridish. The seeds were placed equidistantly from each other on the moist blotter maintaining ten seeds per plate. The lid was placed on it and properly labelled. The plates were incubated inside BOD incubator at $25^{\circ} \mathrm{C}$ for seven days. Observations were recorded on number of seeds showing growth of fungal colonies on them and percentage of infected seeds was calculated.

\section{Isolation and identification of fungi associated with the seed}

The fungi associated with the infected seeds were isolated in pure culture following standard methods of isolation. The fungi developing on seeds in moist blotters were transferred to the PDA slants aseptically. Further purification was made by single spore isolation following dilution plate method.

The colonies developing on the slants were examined microscopically to further ascertain their purity. The pure cultures thus obtained were maintained on PDA slants by sub culturing at 15 days interval.

The fungi isolated from the seeds were identified by taking observations on their colony characters, mycelia characters, colour, size and shape of spores and conidiophores. The characters were compared with description in standard literature for confirmation of identification (Barnett, 1960, Dube, 1983).

\section{Pathogenicity test of isolated fungi}

Four pathogens isolated from the collected seed samples were selected for testing their pathogenicity under greenhouse condition.

Apparently healthy seeds of pea var. Mayurbhanj local free from any blemishes or disease symptoms were surface sterilized. Spore suspension of the test fungi were prepared having $10^{8}$ spores per ml. Surface sterilised seeds were soaked in equal volume of spore suspension separately for fifteen minutes. Inoculated seeds were sown in sterilized sand taken in sterilized plastic pots of $5 \mathrm{~kg}$ capacity at the rate of ten seeds per pot.

Observation was recorded on seedling emergence and occurrence of seed rot and seedling blight diseases. The plants were grown up to 30 days and then gently uprooted to observe symptoms on roots. The trial was replicated thrice. 


\section{Results and Discussion}

\section{Health status of seed samples collected from different places of Odisha}

Thirty six Garden pea seed samples of eight varieties were collected from eight districts of Odisha. The colour of seed varied from yellow to different shades of green. Seed germination of samples was $60-65 \%$ (Table1) which was below IMSCS (i.e. 75\%). Visible symptoms of seed infection were observed as different types of seed discolouration (Fig-1a, b, c) and percentage of discolouration was calculated. The seed discolouration was observed as appearance of dark brown, light brown, black and white patches on seed coat. Seed discolouration varied from $11.0 \%$ to $15.0 \%$. The lowest was in variety Jawahar pea of Koraput district and the maximum was in VL-matter of Bargarh district and local variety of Mayurbhanj district.

The results indicated that seed with higher seed discoloration had lower germination. Samples with higher seed discoloration also contained higher total fungal count with seed. Lowest seed discoloration was observed in variety Kasishakti of Khurdha and local variety of Kandhmal (9\% each) and which had highest germination (66 and 67\%) and lowest total fungal count (40\% and $41.7 \%$ ) respectively. Highest seed discoloration was in variety VL- mater of Bargarh (16.5\%) with lowest germination $(60 \%)$ and highest total fungal count. Five species of fungi, viz. Aspergillusniger, A. flavus, Fusarium sp., Pencillium sp. and Alternaria sp. were found associated with the discoloured seed. (Fig 2 $a, b)$.

The incidence of seed mycoflora like Aspergillusflavus, A. niger, Penicilium sp. were higher (4.0-14.4, 11.9-19.0 and 4.0$6.0 \%$, respectively) than the field fungi like
Fusarium sp. and Alternaria sp., (7.8-10.5\% and $0-2.0 \%$, respectively). About $9-16.5 \%$ seeds in samples were infected and showing visible symptoms of discoloration. Seed health test of the samples revealed association of fungi like Aspergillusflavus, A. niger, Pencilium sp., Fusarium sp., and Alternaria sp., with the seeds. The total fungal count on seeds varied from $40.1 \%$ to $46.5 \%$. Association of fungi like species of Aspergillus, Pencilium and Fusarium with pea seeds have been reported earlier by Begum et al., (2008) and Narayan et al., (2013), and association of Alternariaof sps. have been reported by Javied and Anjum (2006), Marcinkowska (2008) and Wilmanet al.,(2014).

\section{Pathogenicity of isolated fungi}

Pathogenicity of isolated fungi Aspergillusflavus, A. niger, Pencillium sp. and Fusarium sp. were proved under green house condition (Table-2,). Through seed inoculation all the fungi infected the seed and caused seed rot, seedling blight, root rot symptoms and reduced germination. Germination in uninoculated control seeds was $90 \%$. It was reduced to $40 \%$ which was $55.6 \%$ less than that in control. Minimum of $24.4 \%$ reduction in germination was due to Pencilium sp. Seedling blight symptoms appeared 10 days after sowing.

There was black discoloration on stem at soil level and on cotyledons. Maximum seedling blight was due to Aspergillusflavus (14\%) followed by A. niger (10.5\%) and Fusarium sp. $(9.2 \%)$. Blighted seedling often showed black rotting of root tips. Root rot was maximum by Aspergillusniger and Fusarium sp. (20.2 and 20.0\%, respectively). Pencilium sp. didnot cause any seedling blight or root rot. Seedlings in control pots were normal and healthy. 
Table.1 Health status of seed samples collected from different places of Odisha

\begin{tabular}{|c|c|c|c|c|c|c|c|c|c|c|c|}
\hline \multirow[t]{2}{*}{ Place of collection } & \multirow[t]{2}{*}{ Variety } & \multirow{2}{*}{$\begin{array}{c}\text { No. of } \\
\text { sample } \\
\text { collected }\end{array}$} & \multirow{2}{*}{$\begin{array}{l}\text { Seed } \\
\text { colour }\end{array}$} & \multirow{2}{*}{$\begin{array}{c}\text { Germinatio } \\
\text { n }(\%)\end{array}$} & \multirow{2}{*}{$\begin{array}{c}\text { Seed } \\
\text { discoloration }\end{array}$} & \multicolumn{6}{|c|}{ Fungi associated (\%) } \\
\hline & & & & & & A. $f$ & A. $n$ & Pen. sp. & $F$. sp. & $\begin{array}{l}\text { Alt. } \\
\text { sp. }\end{array}$ & TFC \\
\hline Keonjhar & Rachna & 5 & $\begin{array}{c}\text { Bluish } \\
\text { green }\end{array}$ & 65 & 10.5 & 12.5 & 15.0 & 6.0 & 10.3 & 2 & 41.7 \\
\hline Mayurbhanj & Local & 4 & $\begin{array}{c}\text { Bluish } \\
\text { green }\end{array}$ & 65 & 10.0 & 13.8 & 15.5 & 4.0 & 10.5 & 00 & 43.8 \\
\hline Kandhmal & Local & 5 & Green & 67 & 9.0 & 13.5 & 14.2 & 5.0 & 9 & 00 & 41.7 \\
\hline Baragarh & Vl-matar & 5 & Yellow & 60 & 16.5 & 12.8 & 13.5 & 6.0 & 9.5 & 00 & 45.8 \\
\hline Koraput & Jawahar pea & 4 & Green & 65 & 10.0 & 10.5 & 19.0 & 5.5 & 9 & 2.0 & 46.0 \\
\hline Balangir & Local & 4 & $\begin{array}{l}\text { Light } \\
\text { green }\end{array}$ & 61 & 15.0 & 12.2 & 15.0 & 5.2 & 9.5 & 00 & 41.9 \\
\hline Khurdha & $\begin{array}{l}\text { Kasha } \\
\text { shakti }\end{array}$ & 4 & Green & 66 & 9.0 & 14.4 & 11.9 & 6.0 & 7.8 & 00 & 40.1 \\
\hline Sambalpur & GS-10 & 5 & Green & 64 & 10.5 & 11.2 & 13.3 & 5.5 & 8.5 & 2.0 & 40.5 \\
\hline
\end{tabular}

*A. f-Aspergillusflavus, A. $n$ - Aspergillusniger, Pen. sp.-Penciliumsp, Alt. sp- Alternariasp, F. Sp - Fusariumsp, TFC-Total fungal count

Table.2 Pathogenicity test of isolated fungi of garden pea

\begin{tabular}{|c|c|c|c|c|}
\hline Fungi & $\begin{array}{c}\text { Germination } \\
(\boldsymbol{\%})\end{array}$ & $\begin{array}{c}\text { Seed rot } \\
(\boldsymbol{\%})\end{array}$ & $\begin{array}{c}\text { Seedling blight } \\
(\boldsymbol{\%})\end{array}$ & $\begin{array}{c}\text { Root rot } \\
(\boldsymbol{\%})\end{array}$ \\
\hline Aspergillusflavus & 50 & 50 & 14.0 & 14.3 \\
\hline Aspergillusniger & 40 & 60 & 10.5 & 20.20 \\
\hline Penicillium sp. & 68 & 32 & 00 & 00 \\
\hline Fusarium sp. & 65 & 35 & 9.2 & 20.0 \\
\hline $\begin{array}{c}\text { Un inoculated } \\
\text { Control }\end{array}$ & 90 & - & - & - \\
\hline
\end{tabular}


Fig.1 (a, b, c)Different types of seed discolouration

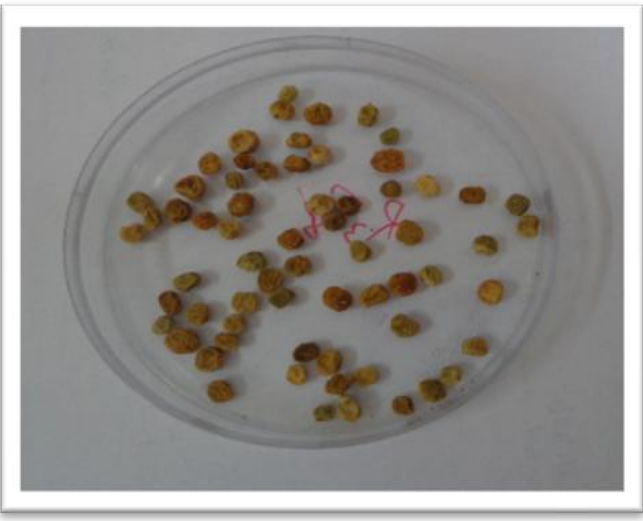

(a)

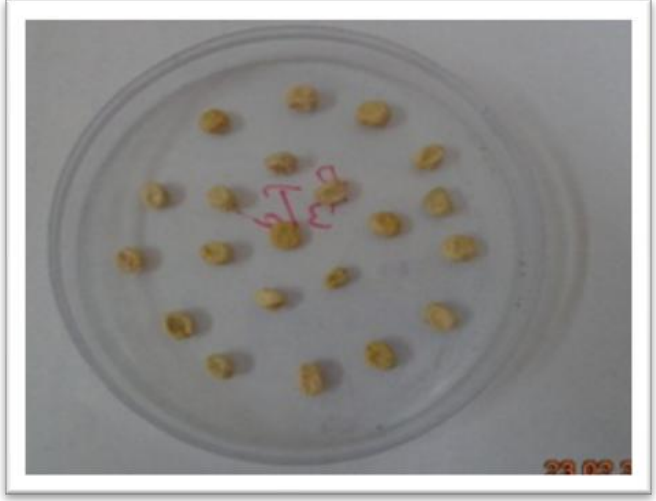

(b)

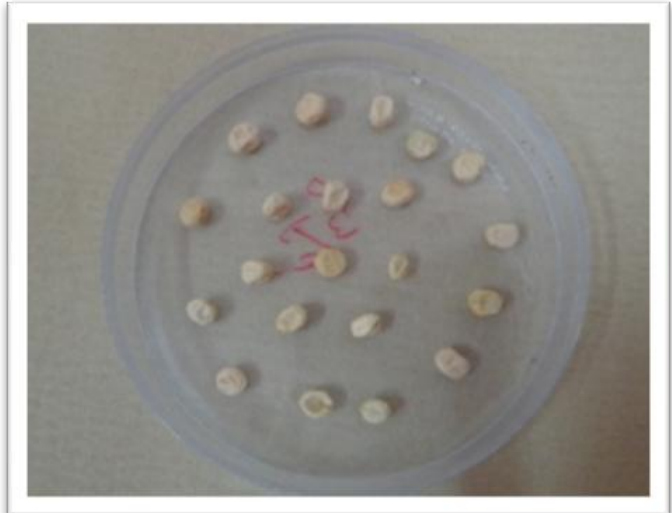

(c) 
Fig.2 (a, b) Fungal infection on discoloured seed

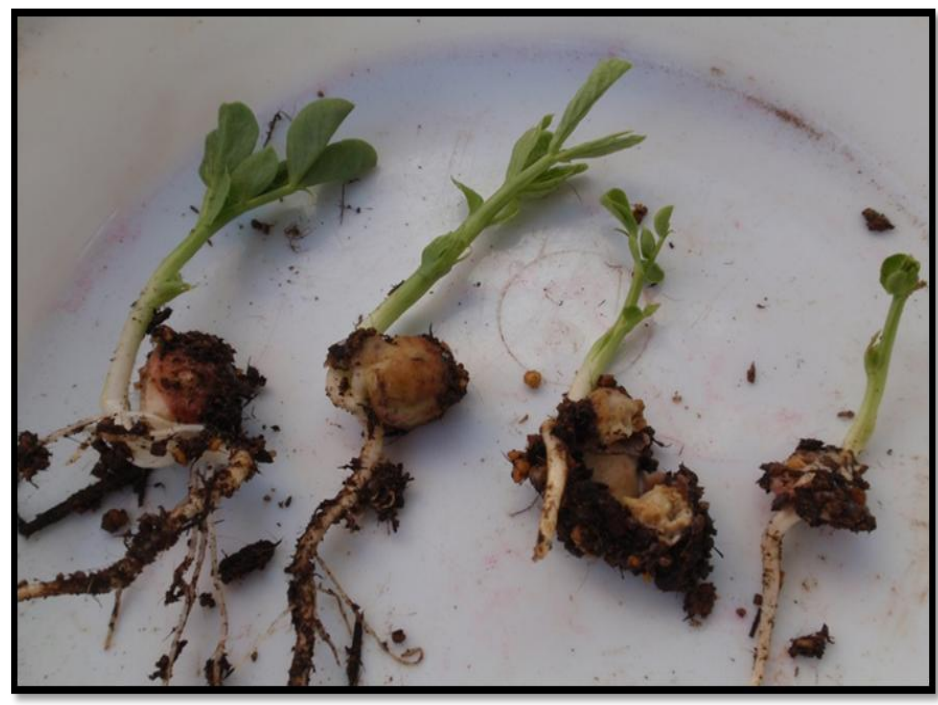

(a)

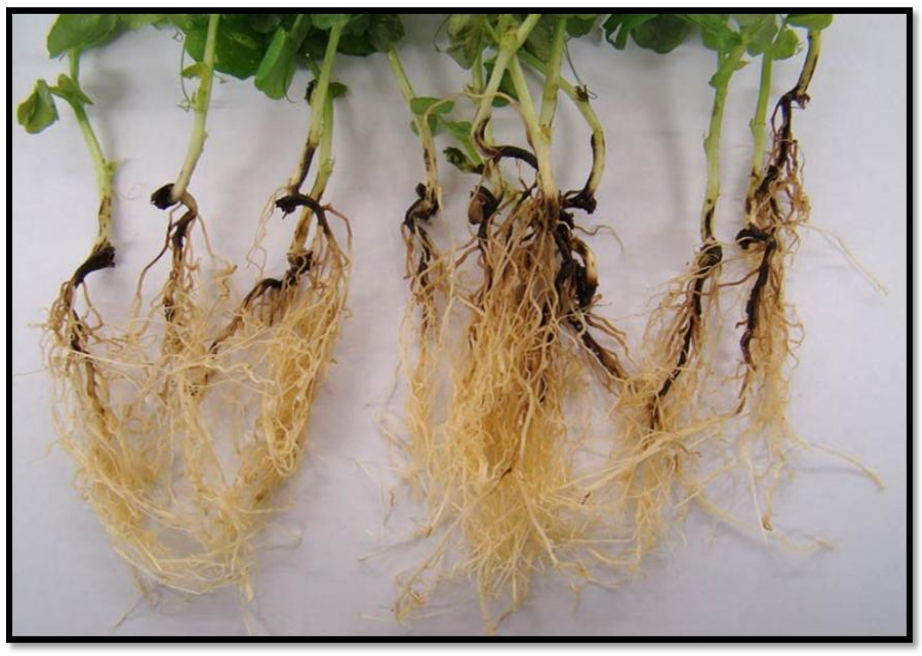

(b)

The present findings are in conformity with results of earlier workers (Begum, 2004; ElMohamedy and El-Baky, 2008; Sharma, 2011). Who have also reported seed and seedling diseases caused by these seed borne fungi.

Seed borne fungi caused reduction in germination. Many of them become active when seeds are sown, where they result in seed decay, root rot and post emergence seedling blight. Consequently, this results in poor plant stand in field which evident from the pathogenicity test. Quality of seed is the most important factor which ensures the productivity and quality of a crop. In vegetable crops like garden pea where seed is costly and its availability is limited, seed quality becomes more important for achieving optimum economic return. As quality seed is in short supply in the state the farmers are using their own seed saved from previous season crop. Hence, it is imperative to assess the quality of farmers saved seed and 
suggested suitable measure for enhancing seed quality.

\section{References}

Bennett AJ and Whipps JM 2008.Beneficial Microorganism Survival on Seed, Roots and in Rhizosphere Soil Following Application to Seed During Drum Priming. Biological Control, 44: 349361.

El-Mohamedy RSR and MMHAbd-El-Baky. 2008. Effect of seed treatment on control of root rots disease and improvement of growth and yield of pea plants. Middle Eastern and Russian Journal of Plant Science and Biotechnology, 2(2): 84 -90.

ISTA 1985. International Rules for Seed Testing. Seed Science and Technology.13:229-255.
Javid A and Anjum T. 2006. Fungi associated , with seeds of some economically important crops in Pakistan. PJST, 1:6878.

Marcinkowska J.2008. Fungi occurrence on seeds of field pea. ActaMycologica., 43(1): 77-89

Narayan. 2013. Study of seed borne fungi of different legumes. DAMA International. 2(1): 2319-4731.

Sharma A, Rathour R and Plaha P. 2010. Induction of Fusarium wilt (Fusarium oxysporumf.sp. pisi) resistance in garden pea using induced mutagenesis and in vitro selection techniques. Euphytica, 173: 345-356.

Wilman K.2014. Pathogenic fungi in pea seeds. ArhHigRadaToksikol;65:329-338

\section{How to cite this article:}

Monalisa, SP. and ChakradharPatra. 2020. Different Garden Pea Varieties Health Status Analysis Procured from Various Locations of Odisha. Int.J.Curr.Microbiol.App.Sci. 9(07): 3797-.3803. doi: https://doi.org/10.20546/ijcmas.2020.907.444 